\title{
Transaminase and D-Amino Acid Oxidase of Trigonopsis variabilis
}

\author{
By S. SENTHESILANMUGANATHAN* aND W. J. NICKEIRSON \\ Institute of Microbiology, Rutgers, The State University, \\ New Brunswick, New Jersey, L.S.A.
}

(Received 4 May 1961)

\begin{abstract}
SUMMLRY
The yeast Trigonopsis variabilis can utilize many single amino acids as sole source of nitrogen. Of the amino acids utilized, the D-isomers are oxidatively deaminated, whilst the L-isomers are transaminated with either $\alpha$-ketoglutarate or pyruvate. The $D$-amino acid oxidase activity of this organism, when grown on DL-methionine as sole source of nitrogen, is the highest yet recorded, and may be recommended for the preparation of keto acids.
\end{abstract}

\section{INTRODLCIION}

It was shown in a preceding paper (SentheShanmuganathan \& Nickerson, 1962a) that Trigonopsis variabilis can utilize a variety of single amino acids as sole source of nitrogen. The growth obtained with $\mathrm{D}$ - and $\mathrm{L}$ - methionine indicated that both the rate of growth and the total yield of organism with the D-isomer were almost twice that obtained with the L-amino acid. To elucidate the mechanism whereby amino acids are metabolized by this yeast, cell-free extracts wcre prepared from organisms grown with methionine or $\left(\mathrm{NH}_{4}\right)_{2} \mathrm{SO}_{4}$ as sole source of nitrogen. The data presented in this paper reveal the presence in this organism of extremely powerful $\mathrm{D}$-amino acid oxidase and transaminase activities.

\section{METHOIS}

Microbiological methods. Trigonopsis variabilis Schachner (CBS 1040) was used throughout this work. The culture medium and conditions of growth were as previously deseribed (SentheShanmuganathan \& Nickerson, 1962a).

Cell-free extracts. Cell-free preparations of the yeast were obtained from organisms grown in the medium containing salts, trace elements, glucose, biotin and thiamine. The nitrogen sources were Du-metlionine or $\left(\mathrm{NH}_{4}\right)_{2} \mathrm{SO}_{4}$ at $25 \mathrm{mg}$. $\mathbf{N} / 100 \mathrm{ml}$. The organisms were harvested by centrifugation, washed twice with distilled water, and suspended in $0 \cdot 1 \mathrm{M}$-phosphate buffer $(\mathrm{pH} 8 \cdot 0)$ at a concentration equivalent to $1.5 \mathrm{~g}$. dry wt. organism/20 ml. buffer. This suspension was subjected to sonic oscillation for $1 \mathrm{hr}$. in a Raytheon $50 \mathrm{~W}$., $9 \mathrm{kc}$. magnetostriction oscillator at a plate voltage of $130 \mathrm{~V}$. and an output voltage of $150 \mathrm{~V}$. The suspension was then centrifuged for $15 \mathrm{~min}$. at $19,600 \mathrm{~g}$ in the high speed angle-head of an International

\footnotetext{
- Present address: Medical Research Institute, Colombo 8, Ceylon.
} 
refrigerated centrifuge. The clear supernatant fluid was dialysed against $0.01 \mathrm{M}$ $\mathrm{KCl}$ at $2^{\circ}$ for $16-18 \mathrm{hr}$. with continuous stirring. The non-dialysable portion contained no debris and was used as the source of enzymes. The extracts from organisms grown with methionine or $\left(\mathrm{NH}_{4}\right)_{2} \mathrm{SO}_{4}$ as sole source of nitrogen will be referred to as extracts $M$ and $\Lambda$, respectively. These were stored at $-20^{\circ}$ until required.

Reagents. 'The amino acids used were described in SentheShanmuganathan \& Nickerson (1962a); 2-ketoglutarate and pyruvate were obtained from the California Corporation for Biochemical Research (Los Angcles 63, California, U.S.A.) and Schwarz Biokesearch, Inc. (Mount Vernon, N.Y.), respectively. Solutions of the amino acids were made in $0.05 \mathrm{M}$-phosphate buffer (pH 8.0) whilst those of the keto acids were prepared in $1 \%(\mathrm{w} / \mathrm{v}) \mathrm{Na}_{2} \mathrm{CO}_{3}$ solution, adjusted to $\mathrm{pH} 8 \cdot(\mathbf{0}$. Pyridoxal phosphate was purchased from the California Corporation for Biochemical Research.

Estimation of protein. The protein content of the preparations was determined by a turbidimetric method of SentheShanmuganathan (1960).

Assay of transaminase activity. The formation of glutamate or alanine from the amino acid and 2 -ketoglutarate or pyruvate was taken as an index of transaminase activity. All incubations were made in duplicate in Thunberg tubes at $37^{\circ}$, gas phase $\mathrm{N}_{2}$ (unless stated otherwisc). Except where indicated, the complete system contained in a total volume of $3.0 \mathrm{ml}$.: pyridoxal phosphate ( $0.04 \mu \mathrm{mole})$, enzyme solution $(0.1 \mathrm{ml}$.$) , and 2$-keto acid (20 $\mu$ mole) in $0.067 \mathrm{M}$-phosphate buffer (pH 8.0). The mixture was incubated for $10 \mathrm{~min}$. before the addition of the amino acid (10 $\mu$ mole 1.- or 20 /mole DL-amino acid). Two control systems were used, che without the amino acid and the other without the keto acid. At the end of the incubation period, $6.0 \mathrm{ml}$. ethanol were added and, after heating in a boiling water bath for 15 min., the denatured protein was removed by centrifugation. Equal volumes of the supernatant fluid were placed on paper chromatograms. The procedure of Woiwod (1949) was adopted for the scparation of amino acids. After drying the papers, the positions of the amino acids were located by spraying with $0 \cdot 1 \%(\mathrm{w} / \mathrm{v})$ ninhydrin in acetone (Dent, 1947).

Quantitative estimation of transaminase activity. The transamination between aspartic acid and 2-ketoglutarate was studied by measuring the change in absorption at $280 \mathrm{~m} \mu$ in the Beckmann spectrophotometer (Cohen, 1955).

Assay of D-amino acid oxidase activity. The extent of amino acid oxidase activity was estimated by measurement of the amount of $\mathrm{O}_{2}$ absorbed by the substrate (Krebs, 1951). 'The uptake of $\mathrm{O}_{2}$ was followed manometrically in Warburg manometers by conventional techniques. Unless stated otherwise, all manometric experiments were carried out at $30^{\circ}$, in $0.05 \mathrm{M}$-phosphate buffer (pH 8.0) with air as zas phase. The centre well contained $0.2 \mathrm{ml}$. of $10 \%(\mathrm{w} / \mathrm{v}) \mathrm{NaOII}$ to trap any $\mathrm{CO}_{2}$ produced. Reactions were initiated by the addition of the substrate from the side arm.

Growth measurements. Growth was measured in terms of dry weight, as described in SentheShanmuganathan \& Nickerson (1962a). 


\section{RFSUI.TS}

The presence of transaminase activity in extracts prepared from organisms grown in methionine or in $\left(\mathrm{NH}_{4}\right)_{2} \mathrm{SO}_{4}$ as sole souree of nitrogen, was tested with a variety of single amino acids as amino-group donors, and 2 -ketoglutarate or pyruvate as amino-group acceptors. 'These estimations were carried out qualitatively by paper chromatography. Except with aspartic acid, no quantitative estimations were conducted. The results (Table 1 ) indicate that of the fourteen amino acids tested all. with the exception of proline, transaminated with 2 -ketoglutarate in the presence of extracts $\mathbf{A}$ and $\mathbf{M}$. In nine cases transaminase activity (glutamate formation) was observed with the DL form of the amino acid. In the other five cases the $\mathrm{L}$ form was active and it scemed likely that the $\mathrm{r}$. form of the $1 \mathrm{l}$. mixtures might be the artive component. 'This was tested and shown to be true with methionine since L-methionine but not 1)-methionine gave glutamate. When 2-ketoglutarate was replaced by pyrurate, only six of the fourteen acids (namely, $x$-aminobutyric acid, serine. thrconinc, tryptophan, tyrosine, valine) transaminated in the presence of either extract.

Table 1. Transaminase activity in cell-free prtracts of 'Trigonopsis variabilis prepared

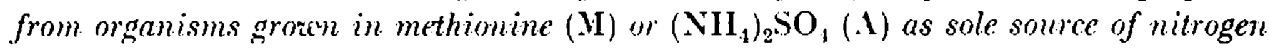

The complete system contained in a total volume of $3.0 \mathrm{ml}$.: pyridoxal phosphate $(0 \cdot 0+\mu$ mole), enzyme solution $(0.1 \mathrm{ml}$.$) , and 0$ xo acid $(20 /$ mole) in $0.067 \mathrm{~m}$-phosphate buffer ( $\mu I \mathrm{8} \cdot 0)$. The mixture was pre-incubated for $10 \mathrm{~min}$. before the amino acid was added (10 $\mu$ mole 1. or $20 \mu$ mole $1 \mathrm{~L}$ ). Gas phase $\Sigma_{2}$; temp. $37^{\circ}$; incubation period, 60 min. Extract $M$ from organism grown with methionine, extract $A$ from organism grown with $\left(\mathrm{NH}_{4}\right)_{2} \mathrm{SO}_{4}$.

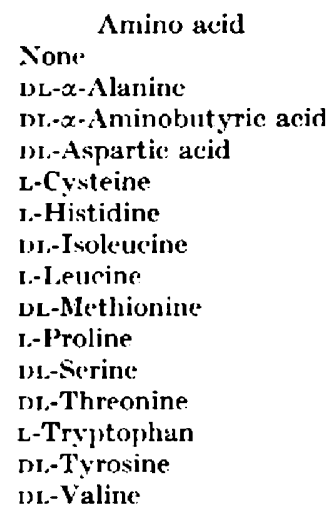

\begin{tabular}{ccccc} 
Glutamate formation & \multicolumn{3}{c}{ Alanine formation } \\
\cline { 2 - 4 } Fix. II & Fxt. A & Ext. II & Fxt. A \\
- & - & - & - \\
+ & + & - & - \\
+ & + & + & + \\
+ & + & - & - \\
+ & + & - & - \\
+ & + & - & - \\
+ & + & - & - \\
+ & + & - & - \\
+ & + & - & - \\
- & - & - & - \\
+ & + & + & + \\
+ & + & + & + \\
+ & + & + & + \\
+ & + & + & + \\
+ & + & + & +
\end{tabular}

Transamination between aspartic acid and 2-ketoglutarate

To a quartz optical cell of the Beckmann spectrophotometer were added $0.1 \mathrm{ml}$. cell-free extract, $1.0 \mathrm{ml}$. $0.05 \mathrm{w}$-phosphate buffer ( $\mathrm{pH} \mathrm{8.0)}$ ). Dr-aspartic acid (20 $\mu$ mole) and pyridoxal phosphate $(0.04 \mu$ molc). After mixing, 2-ketoglutarate (20 $\mu$ mole) was added and the change in absorption at $280 \mathrm{~m} \mu$ was measured. 'Two controls were run simultaneously, one without the keto and the other without the amino acid. 'The results of such an experiment are shown in Fig. 1, where it is seen that both extracts $\mathrm{A}$ and $\mathrm{X}$ catalyse the transfer of amino group from aspartic acid 
to 2-ketoglutarate. The rate of transamination with extract $\mathbf{M}$ was higher than that observed with extract A $(0.060 \mu \mathrm{mole} / \mathrm{min}$. as compared to $0.045 \mu \mathrm{mole} / \mathrm{min}$. $)$. When extract $\mathbf{M}$ was used, one of the control optical cells (which contained only aspartic acid) produced $0.01 \mu$ mole oxaloacetic acid/min. Such behaviour was not observed with extract $\mathbf{A}$, implying that the extract $\mathbf{M}$ possessed a very slight amino acid oxidase activity.

\section{Amino acid oxidase activity}

The amino acid oxidase activity in extracts $\mathbf{A}$ and $\mathbf{M}$ was studied by measuring the $\mathrm{O}_{2}$ uptake by the substrate amino acid. All experiments were carried out with the DL-isomers. Of the nineteen amino acids tested (Table 2), $\mathrm{O}_{2}$ uptake was observed with fifteen of them, but the rates of $\mathrm{O}_{2}$ absorption differed appreciably. With extract $M$, homocysteine was found to be the best substrate (415 $\mu \mathrm{l} . \mathrm{O}_{2} / \mathrm{hr} . / \mathrm{mg}$. protein). When extract $A$ was used, homocysteine was again found to be the best (136 $\mu \mathrm{l} . \mathrm{O}_{2} / \mathrm{hr} . / \mathrm{mg}$. protein). With most of the amino acids studied, the rate of $\mathrm{O}_{2}$ uptake in the presence of extract $M$ exceeded (by more than three times) the rate observed with extract $A$.

Table 2. D-Amino acid oxidase activity in cell-free extracts of Trigonopsis variabilis prepared from organisms grozon in methionine (M) or $\left(\mathrm{NH}_{4}\right)_{2} \mathrm{SO}_{4}(\mathrm{~A})$ as sole source of nitrogen

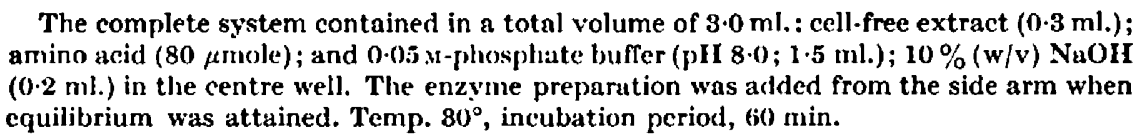

\begin{tabular}{|c|c|c|c|}
\hline \multirow[b]{2}{*}{ Amino acid } & \multicolumn{3}{|c|}{$\mu \mathrm{l} . \mathrm{O}_{2}$ uptake/hr./mg. protein } \\
\hline & Fxtract $\mathbf{M}$ & Extract $\mathbf{A}$ & $\begin{array}{c}\text { Penicillium } \\
\text { chrysogenum } \\
\text { (Krebs, 1051) }\end{array}$ \\
\hline None & 0 & 0 & - \\
\hline Di.-Homorysteine & $41 \tilde{3}$ & 136 & - \\
\hline DL-Methionine & 800 & 107 & 188 \\
\hline nL-nor-Valine & 205 & 38 & - \\
\hline D1.- $\alpha$-Aminobutyric acid & 201 & 55 & 134 \\
\hline Dt.-Valine & 200 & $3 \gamma$ & 112 \\
\hline Dt.-Phenylalanine & 172 & 19 & 126 \\
\hline DL- $\alpha$-Alanine & 153 & $3 \mathrm{I}$ & 146 \\
\hline DL-Ifeucine & 151 & 30 & 208 \\
\hline DL-Tryptophan & 122 & 6 & 38 \\
\hline DL-nor-Leurine & 120 & 30 & 128 \\
\hline ItL-Isoleucine & 10.5 & 22 & 64 \\
\hline DL-Homocystine & 104 & 28 & - \\
\hline DL-Tyrosine & 86 & 19 & - \\
\hline Du-Serine & 48 & 6 & o \\
\hline DL-I.ysine & 35 & 3 & 26 \\
\hline 1) r.-'Threonine & 14 & 4 & 14 \\
\hline DL-Aspartic acid & 8 & 1 & $\mathbf{0}$ \\
\hline nu-Ornithine & 7 & 0 & - \\
\hline DL- $x$-Amino isobutyric acid & 5 & 0 & - \\
\hline
\end{tabular}

To learn whether the $\mathbf{D}, \mathrm{L}$, or both isomers were deaminated, four amino acids were tested in their $\mathrm{L}$ form (leucine, histidine, valine, phenylalanine). There was no uptake of $\mathrm{O}_{2}$ with any of these anino acids in the presence of extracts $\mathrm{A}$ or $\mathrm{M}$, indi- 
cating that the amino acid oxidase was specific for the D-isomer only. For comparison, the D-amino acid oxidase activity obtained with Penicillium chrysogenum Q 176 (Krebs, 1951, based on data of Emerson, Puziss \& Knight, 1950) is also given in Table 2. The results obtained with Trigonopsis variabilis run almost parallel to those obtained with Penicillium chrysogenum. This is the first time the presence of D-anino acid oxidase activity has been demonstrated in a yeast. The organisms grown with methionine as sole source of nitrogen are the richest source of amino acid oxiduse found to date. $T$. variabilis may therefore be recommended as a potential source of $\mathrm{D}$-amino acid oxidase for the preparation of keto acids.

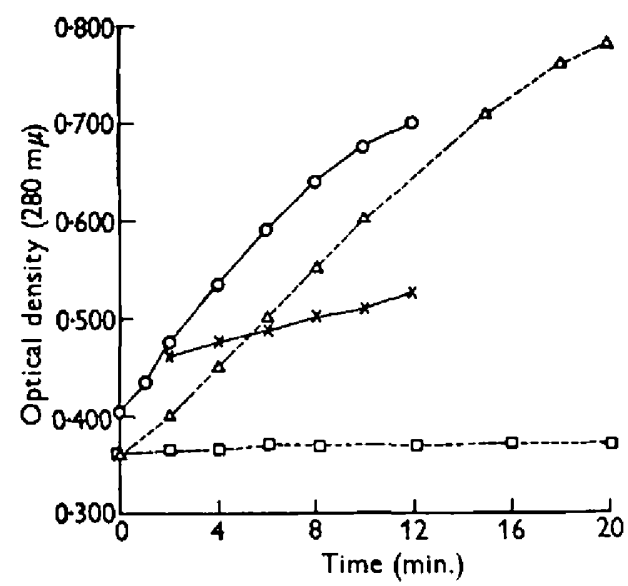

Fig. 1

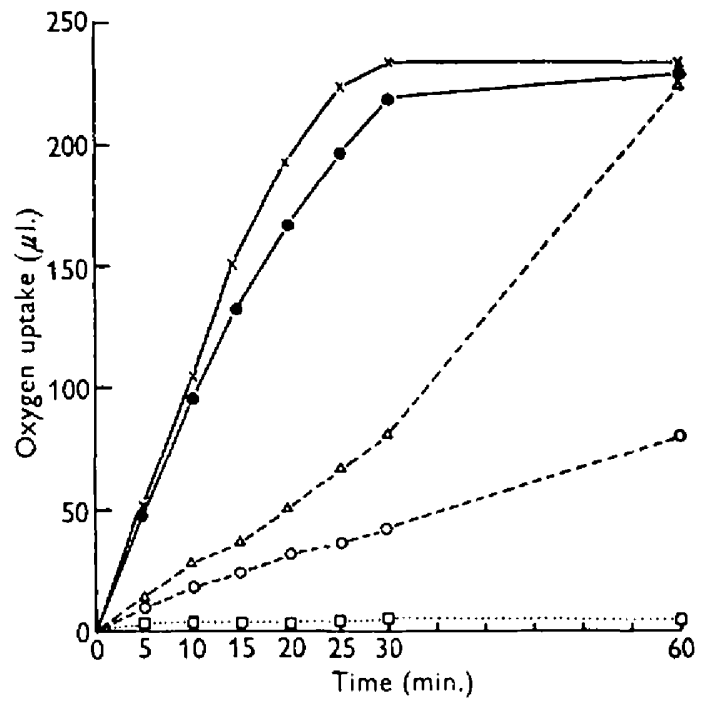

Fig. 2

Fig. 1. Transamination between 2-ketoglutarate and aspartic acid by cell-free extracts of Trigonopsis tariabilis grown with nL-methionine or $\left(\mathrm{NH}_{4}\right)_{2} \mathrm{SO}_{4}$ as sole sources of nitmgen. 'The quartz cell of the Beckman apectrophotometer contained in a total volume of 3.0 ml. : extract $(0.1 \mathrm{ml}$.), phosphate buffer $(0.05 \mathrm{M} ; \mathrm{pH} 8.0 ; 1.0 \mathrm{ml}$.), ni.-aspartic acid (20 $\mu$ mole); pyridoxal phosphate $(0 \cdot 04 \mu$ mole); 2-ketoglutarate (20 $\mu$ mole). $\mathrm{O}-\mathrm{O}$ Complete system containing extracts of methionine grown cells (M): $\times-\times$ complete system (M), less 2-ketoglutarate; $\Delta---\Delta$ complete system containing extracts of $\left(\mathrm{NH}_{4}\right)_{2} \mathrm{SO}_{4}$ grown cells $(A) ; \square---\square$ complete system $(A)$, less 2-ketoglutarate.

Fig. 2. $\mathrm{n}-\mathrm{A}$ mino acid oxidase activity of cell-free extracts of cells of Trigonopsis variabilis grown w'ith bL-methionine or $\left(\mathrm{NIH}_{4}\right)_{2} \mathrm{SO}$, as sole source of nitrogen. $\mathrm{O}_{2}$ uptuke meusured in Wurburg manometers. The complete system contained, in a total volume of $3.0 \mathrm{mul} .:$ cell-free extract, $0.9 \mathrm{ml} .=1.5 \mathrm{mg}$. protein ; $0.0 .5 \mathrm{st}$-phosphute buffer (pll 8.0); $1.5 \mathrm{ml}$.); $10 \%(w / v)$ NaOH $(0.2 \mathrm{ml}$ ) $)$ in the centre well. Reaction was initiated by the addition of tlic amino acid $\left(10 \mu\right.$ mole) from the side arm; temp. $30^{\circ} . \times-\times$ Fxtract $\mathbf{M}$, nLmethionine; $\longrightarrow$ extract $M$, DL-alanine; $\triangle--\Delta$ extract A, DL-methionine ; $O---O$ extract $A$, bL-alanine; $[\cdots \cdots \square$ extracts $\mathbf{A}$ or $\mathbf{M}$.

To follow the rate of oxidation of the amino acids, $\mathrm{O}_{2}$ consumption was estimated manometrically at 10 -min. intervals. For both $\mathrm{D}$ - and L-amino acids the rate of $\mathrm{O}_{2}$ uptake with extract $M$ was more than three times that obtained in the presence of extract A (Fig. 2). In $30 \mathrm{~min}$. the substrates were completely deaminated by extract $M$, but incubation for $60 \mathrm{~min}$. with extract $A$ was required to achieve complete deamination of methionine and about one-third of the alanine. From 
these results, and those in 'Table 2, it may be concluded that incubation of Trigonopsis variabilis with an amino acid as nitrogen sourec, can result in stimulation of deaminase activity by more than threcfold.

To establish that the end product of the reaction between an amino acid and oxygen in the presence of the extracts was the keto acid corresponding to the arrino acid (reaction 1 ):

$$
\mathrm{CII}_{3}-\mathrm{S}-\mathrm{CH}_{2}-\mathrm{CH}_{2}-\mathrm{CH}-\mathrm{COOH}+{ }_{2}^{\frac{1}{2} \mathrm{O}_{2}->} \mathrm{CH}_{3}-\mathrm{S}-\mathrm{CII}_{2}-\mathrm{CII}_{2}-\mathrm{CO}-\mathrm{COOH}+\mathrm{NII}_{3}
$$

the product was isolated as the 2:4-dinitrophenyl hydrazone.

As a typical example, reaction (1) was examined in the cuse of methionine. When $\mathrm{O}_{2}$ uptake ceased in the reaction flask, protein was precipitated with trichloroacetic acid (10\%, $\% / v$, final concentration) and removed by centrifugation. The supernatant fluid was then extracted with ether and the ether extract dried with anhydrous $\mathrm{Na}_{\mathrm{g}} \mathrm{SO}_{4}$. On removal of the ether, a thick syrupy liquid remained. 'This was treated with $5 \mathrm{ml} . \mathrm{N}-\mathrm{HCl}$ and shaken with $10 \mathrm{ml}$. of a saturated solution of 2:4-dinitrophenylhydrazine in $\mathrm{N}$-HCl. After standing at. $2^{\circ}$ for $12 \mathrm{hr}$., the precipitated mass was filtered, washed with $\mathrm{N}-\mathrm{HCl}$ and distilled water until the washings were colourless. The crude yellow product was recrystallized three times from cthanol + water until a constant melting point was obtained. The recrystallized product melted at $150^{\circ}$. The keto acid, $\alpha$-keto- $\gamma$-methiolbutyric acid, corrcsponding to methionine, was also prepared according to the method described by Acister (1952) by using acetone powders of hog kidney eortex as source of I)-amino acid oxidase. 'The 2:4-dinitrophenylhydrazone was also prepared from this keto acid as described above. The melting point was found to be $150^{\circ}$ (Meister, 1957, m.p. $150^{\circ}$ ). $A$ mixed melting determination also gave a value of $150^{\circ}$.

Table 3. Growth of Trigonopsis variabilis under anarrobic conditions with $\left(\mathrm{NH}_{4}\right)_{2} \mathrm{SO}_{4}$ or 1)-, 1.-, or DL-methionine as sole source of nitrogen

After inoculation, the flasks were flushed with $\mathbf{N}_{2}$, stopjered with rubber stoppers

\begin{tabular}{|c|c|}
\hline Nitrogen source & $\begin{array}{l}\text { Growth after } \\
72 \text { hr. of } \\
\text { inculhation } \\
\text { (ung. dry wt.fl.) }\end{array}$ \\
\hline None & 5 \\
\hline$\left.\left(\mathrm{NH}_{4}\right)_{2} \mathrm{SO}\right)_{4}$ & 372 \\
\hline Dr-Methionine & $14 ; 5$ \\
\hline 1.-Methionine & 135 \\
\hline D-Mlethionine & 13 \\
\hline
\end{tabular}
carrying Bunsen valves, and incubated at $28^{\circ}$ with continuous agitation for 72 hr.; medium at pII $6 \cdot 0$.

From these findings it is apparent that Trigomopsis zariabilis metabolizes amino acids by transamination or by deamination. The $\mathrm{D}$-isomer is deaminated oxidatively

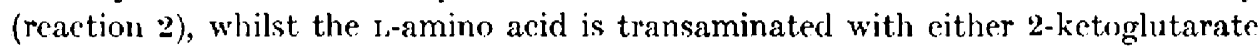
or pyruvate (reaction 3 ):

(2) D-Methionine $+\frac{1}{2} \mathrm{O}_{2} \rightarrow \alpha-0 \times 0-\gamma$-methiol butyric acid $+\mathrm{NH}_{3}$

(3) L-Methionine + 2-ketoglutarate or pyruvate $\rightarrow 2$-keto- $\gamma$-methiol butyric acid + glutamic acid or alanine. 
If only reactions 2 and 3 are available to the organism, then this ycast should be able to utilize only the 1,-isomer, and not the $\mathrm{D}$-amino acid, in growth under anacrobic conditions. To test this supposition, $\left(\mathrm{NH}_{4}\right)_{2} \mathrm{SO}_{4}$ and 1)-, L--, or Dl.-methionine was used as sole nitrogen source in the medium previously described. After inoculation, the llasks were llushed with $\mathrm{N}_{2}$, and incubated at $28^{\circ}$. At the end of $72 \mathrm{hr}$. of incubation, growth was measured in terms of dry weight of organism. In Table 3 it may be seen that with $\mathrm{L}^{-}$or $1 \mathrm{~L}$-methionine growth was very much greater than that obtained with the D-isomer.

\section{I)ISCLSSION}

D-Amino acid oxidase activity has been demonstrated in cell-free preparations obtained from a number of filamentous fungi (including Neurospora crassa, $N$. sitophila, Aspergillus niger, and several species of Penicillium; see Krebs, 1951) and from a few bacteria. The enzyme has been found in liver and kidney of all vertebrates in which it has been sought. In view of the very high activity of this enzyme in our preparations from Trigonopsis variabilis, it is somewhat remarkable that this is, apparently, the first report on the presence of 1 -amino acid oxidase in a yeast. Since the recognition of the existence of separate enzyme systems for the oxidation of $1 .-$ and of $\mathrm{D}$-amino acids (Krebs, 1935) it is also somewhat remarhable that "no satisfactory answer can be given to the question of the physiological significance of D-amino acid oxidases' (K rebs, 1951). 'The statement, apparently, holds good today. However, as Krels pointed out in his review, D-amino acid oxidase is a uscful chemical tool for the determination of the presenec of $\mathrm{n}$-amino acids, and for the preparation of $\alpha$-kcto acids from several of the $\alpha$-amino acids. In $T$. variabilis there is provided an organism, easily grown, that is a rich source of $\mathrm{v}$-amino acid oxidase.

'This work was supported in part by grants from the National Institutes of IIealth, C.S. Public Health Service. One of us (S.S.) was Pfizer Postdoctoral Fellow in Microbiology, on leave of absence from the Medical Research Institute. Colombo, Ceylon, when this work was donc.

\section{REFERENCES}

Cones, P. P. (1955). Estimation of animal transaminases. In Methods in Enzymology, vol. 2. p. 178. Hd. by S. P. Colowick \& N. O. Liaplan. New York: Academic Press Inc.

Den T, C. F. (19.4\%). The anino-aciduria in Fanconi Syndrome. A study making extensive use of techniques based on paper partition chromatography. Biochem. I. 41, 240.

Emrirson, R. L., Prziss, M. \& Krymt, S. G. (1950). The 1)-amino acid oxidase of molds. Arch. Biorhem. 25, 299.

Kurers, II. A. (1935). Metabolism of amino-acids. IIr. Deamination of amino acids. Biochem. J. 29, 1620.

KnFBs, 11. A. (1951). Oxidation of amino acids. In The Enzymes, vol, 2, part 1, p. 499. Fd. by J. S. Sumner \& K. Myrbä̈k. New York: Academic l'ress Inc.

Mrister, A. (1952). Enzymatic preparation of $\alpha$-keto acids, J. biol. Chem. 197, 309.

Mristen, A. (1957). Biochemistry of the Amino Acids, p. 79. New York: Acadenic. Press Ine.

Sentrishanguganatmax, S. (1960). The purification and properties of the tyrosine-2oxo-glutarate transaminase of Saccharomyces cereisiale. Binchem. J. 77, 619.

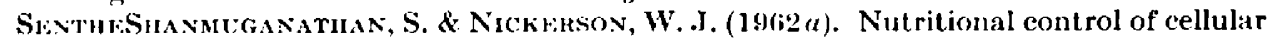
form in Trigonopsis variabilis. J. gen. Microbniol. 27, 4:37.

Worwood, A. J. (1949). A method for the estimation of micro amounts of amino nitrogen and its application to paper partition chromatography. Biochem. J. 45, 412. 